\title{
Implications for dry matter production and nitrogen management as soils develop following 'humping and hollowing' on the West Coast
}

\author{
A.J. HORROCKS, S.M. THOMAS, C.S. TREGURTHA, \\ M.H. BEARE and E.D. MEENKEN \\ The New Zealand Institute for Plant \& Food Research Limited, Private Bag 4704, Christchurch \\ Abie.Horrocks@plantandfood.co.nz
}

\begin{abstract}
Humping and hollowing of wet and infertile soils on the West Coast is a practice used to improve drainage and pasture dry matter production (DMP). There is little information for farmers to help manage nutrient responses on these new soils. On-farm trials were established to investigate how time following modification ( 1,5 or 10 years), position (humps, slopes and hollows) and fertiliser $\mathrm{N}$ rates (0 to $480 \mathrm{~kg} \mathrm{~N} / \mathrm{ha} /$ yr) affected DMP. Soil organic matter tended to be greatest on the oldest sites; 10-year-old sites had soil organic $\mathrm{C}$ and $\mathrm{N}$ concentrations and stocks that were up to twice those of the 1-year-old sites. Understanding the rate of soil organic matter accumulation in humps and hollows and how this affects nutrient supply, water storage and DMP will help farmers adjust their fertiliser applications to target specific production and environmental goals.
\end{abstract}

Keywords: nitrogen, fertiliser, soil carbon, pasture production

\section{Introduction}

Poor drainage is a major constraint on agricultural production for large areas of West Coast "pakihi" soils in the South Island of New Zealand. These soils are acidic, infertile and often podsolised with distinct impermeable iron pans (Molloy 1998). To overcome waterlogging and nutrient availability constraints in this high rainfall environment an extreme landform modification - humping and hollowing - is practiced. Large machinery is used to excavate the "hollows", removing the soil and breaking through the upper iron pans, creating wide surface drains. The "humps" are built up from the excavated soil deposited on to the original soil surface. This practice drastically alters the landscape with the hump-hollow sequence recurring every 45 to $50 \mathrm{~m}$ across the farmland. The height difference from the bottom of the hollow to the top of the hump is about $3 \mathrm{~m}$; the actual gradient of the contours depends on the depth to the gravels and iron pan. The wide hollows underlain by impermeable iron pans and the increased relief of the humps, improve the surface runoff and drainage and thereby reduce waterlogging. This practice has increased the productive capacity of the land and in particular has enabled dairy expansion in the West Coast region over the last 15 years.

Both the landscape and soils are radically different from how they were before modification. The resulting surface layers of the humps and hollows have low fertility. A recent fertiliser response study by Morton \& Roberts (2006) on newly modified "pakihi" soils concluded that high rates of $\mathrm{N}, \mathrm{P}$ and $\mathrm{S}$ are required to maximise dry matter production (DMP) in the early stages after development and $\mathrm{N}$ rates of up to $480 \mathrm{~kg}$ $\mathrm{N} / \mathrm{ha} / \mathrm{yr}$ were recommended. However, a high rate of fertiliser application also increases the risk of nutrient losses. For example, large amounts of $\mathrm{P}$ have been measured in leaching and runoff from hump and hollow soils in this high rainfall environment (McDowell 2008).

The modified surface layers of the humps and hollows tend to be lower in organic matter than the original pakihi soils. Much of the original soil material is buried when the humps are created. However, the amount and quality of soil organic matter (SOM) can rapidly increase from a $10 \mathrm{t} \mathrm{C} / \mathrm{ha}(0-15 \mathrm{~cm})$ average immediately after modification to about $45 \mathrm{t} \mathrm{C/ha} \mathrm{(0-15}$ $\mathrm{cm}) 10$ years after modification (Thomas et al. 2007). Furthermore, the rate of SOM accumulation is affected by the landform type, accumulating faster on humps than hollows (Thomas et al. 2007).

The low initial soil fertility after soil modification and rapidly changing SOM following the land development has important implications for managing nutrients efficiently for pasture production. However, land managers have very little information to help them manage $\mathrm{N}$ inputs to these soils as they develop over time. This paper reports results from field trials examining how changes in SOM following soil modification affect nutrient supply and, in turn, fertiliser $\mathrm{N}$ responses for pasture growth. How this information and the results of on-going research can help farmers efficiently manage these 'new' soils is discussed.

\section{Methods}

Field trials were conducted on three dairy farms at Atarau $\left(42^{\circ} 16^{\prime} \mathrm{S}, 171^{\circ} 32^{\prime} \mathrm{E}\right)$, Arahura $\left(42^{\circ} 44^{\prime} \mathrm{S}, 171^{\circ} 10^{\prime} \mathrm{E}\right)$ and Kotuku $\left(42^{\circ} 31^{\prime} \mathrm{S}, 171^{\circ} 30^{\prime} \mathrm{E}\right)$, all within $35 \mathrm{~km}$ of 
Greymouth on the West Coast of the South Island. All farms had extensive areas of humping and hollowing and covered a range of ages since modification. The annual rainfall in this area is typically $>2500 \mathrm{~mm} / \mathrm{yr}$ and the mean annual temperature at Greymouth is $12.1^{\circ} \mathrm{C}$.

The objectives of the field trials were to determine how paddock age (i.e. time since modification) and position on the landform (hump, slope or hollow) affect the DMP response to different fertiliser $\mathrm{N}$ rates. The field trials were established on nine hump and hollow sites across the three farms.

The experiment was designed as a randomised split criss-cross design. The main treatment was time since modification (Age) with three Ages - 1, 5 and 10 years since humping and hollowing, and three replicates

Table 1 Fertiliser $\mathrm{N}$ rates for the 2008-2009 growing season.

\begin{tabular}{|c|c|c|c|c|c|}
\hline \multicolumn{6}{|c|}{ Fertiliser N (kg N/ha/yr) } \\
\hline & 0 & 120 & 240 & 360 & 480 \\
\hline Aug & & 40 & 40 & 60 & 60 \\
\hline Sep & & & 40 & 60 & 60 \\
\hline Oct & & & 40 & 60 & 60 \\
\hline Nov & & 40 & & & 60 \\
\hline Dec & & & 40 & 60 & 60 \\
\hline \multicolumn{6}{|l|}{ Jan } \\
\hline Feb & & & 40 & 60 & 60 \\
\hline Mar & & 40 & & & 60 \\
\hline Apr & & & 40 & 60 & 60 \\
\hline
\end{tabular}

of each with one 5 year site being removed from the data-set due to unplanned grazing. Each of the sites was made up of 15 plots (each $4 \times 1 \mathrm{~m}$ ) with three Position treatments (hump, slope and hollow) and five $\mathrm{N}$ treatments $(0,120,240,360,480 \mathrm{~kg} \mathrm{~N} / \mathrm{ha} / \mathrm{yr})$ applied (as urea) in a criss-cross layout. Typically, the distance from the bottom of the hollow to the top of the hump was $18 \mathrm{~m}$. The slope plots were midway between the hollow and the hump plots. The fertiliser $\mathrm{N}$ treatments were positioned parallel to the slope, straddling the top of the hump, the mid-point of the slope and the bottom of the hollow, with a $1 \mathrm{~m}$ buffer strip between adjacent $\mathrm{N}$ treatment plots. Due to a lack of farms with the range of different aged humps and hollows, the third replicate was split across two farms.

Fertiliser $\mathrm{N}$ treatments started in late winter (August) 2008 and ended late autumn (April) 2009. The number of applications varied depending on the $\mathrm{N}$ treatments and were applied at rates of 40 or 60 $\mathrm{kg} \mathrm{N} / \mathrm{ha}$. Applications were timed to meet anticipated seasonal pasture responses (Table 1). Applications of $\mathrm{P}$, $\mathrm{K}$ and $\mathrm{S}$ were sufficient to ensure that these nutrients were not limiting DMP, and to account for the removal of clippings based on the work of Morton \& Roberts (2006). Animals were excluded from the field trial sites 3 months before and for the duration of the trial, to reduce the effect of residual $\mathrm{N}$ from urine and dung on DM responses to fertiliser $\mathrm{N}$.

DMP was determined 11 times between August 2008 and July 2009 from strips mown from each plot to a height of $7 \mathrm{~cm}$ using a rotary mower. Total clippings

Table 2 Total soil carbon and nitrogen $(\%)$ levels $(0-15 \mathrm{~cm})$ from sites of three different ages since modification (3 reps) measured from humps, slopes and hollows.

\begin{tabular}{|c|c|c|c|c|c|c|c|c|c|}
\hline \multirow{2}{*}{$\begin{array}{l}\text { Age } \\
\text { (Yrs) }\end{array}$} & \multicolumn{3}{|c|}{ C \% } & \multicolumn{3}{|c|}{$\mathrm{N} \%$} & \multicolumn{3}{|c|}{$\mathrm{C}: \mathrm{N}$} \\
\hline & Hump & Slope & Hollow & Hump & Slope & Hollow & Hump & Slope & Hollow \\
\hline 1 & 3.66 & 4.65 & 2.75 & 0.21 & 0.25 & 0.12 & 17.6 & 20.1 & 21.9 \\
\hline 5 & 4.60 & 4.63 & 3.13 & 0.24 & 0.22 & 0.18 & 18.8 & 20.2 & 18.1 \\
\hline 10 & 5.92 & 5.53 & 4.19 & 0.37 & 0.34 & 0.26 & 16.0 & 15.9 & 16.9 \\
\hline
\end{tabular}

$\mathrm{LSD}_{5 \%}$ for $\mathrm{C} \%=2.11, \mathrm{~N} \%=0.12$ and $\mathrm{C}: \mathrm{N}=2.07$

Table 3 Stone corrected total soil carbon and nitrogen levels $(0-15 \mathrm{~cm})$ from sites of three different ages since modification $(3$ reps) measured from humps, slopes and hollows.

\begin{tabular}{lcccccc}
\hline Age & & C (t/ha) & & & \multicolumn{2}{c}{$\mathrm{N}(\mathrm{t} / \mathrm{ha})$} \\
$($ Yrs $)$ & Hump & Slope & Hollow & Hump & Slope & Hollow \\
1 & 24.9 & 34.0 & 18.7 & 1.44 & 1.88 & 0.85 \\
5 & 34.0 & 42.5 & 16.6 & 1.71 & 1.92 & 0.93 \\
10 & 46.7 & 42.9 & 28.9 & 2.89 & 2.66 & 1.79 \\
\hline
\end{tabular}


were weighed and a $150 \mathrm{~g}$ subsample was removed for dry matter determination. Total soil $\mathrm{C}$ and $\mathrm{N}$ were determined from a composite of four samples (0-15 $\mathrm{cm}$ ) taken in August 2008 at each of the three positions (hump, slope and hollow) at the nine sites. Samples were mixed thoroughly, sieved $<2 \mathrm{~mm}$ diameter, ground and oven-dried overnight at $60^{\circ} \mathrm{C}$, and then analysed for total organic $\mathrm{C}$ and $\mathrm{N}$ by the Dumas combustion method using a TruSpec CN analyser (Leco Australia Pty., NSW, Australia) operating at $950^{\circ} \mathrm{C}$. Soil C and $\mathrm{N}$ stocks were determined accounting for the volume of stones measured from two sites at each position for each paddock using the method described by Thomas et al. (2007). Pasture species composition was determined from a composite of ten samples taken from humps, slopes and hollows at each field site in August 2008.

\section{Statistical analysis}

Treatment effects of Age and Position on total soil C and $\mathrm{N}$ (concentrations and stocks), cumulative DMP and species composition were analysed by ANOVA; an indication of the variability associated with means is given by least significant difference $\left(\operatorname{LSD}_{5 \%}\right)$. Regression analysis was used to estimate linear effects of $\mathrm{N}$ fertiliser on DMP for Age and Position treatments. The effects of Age and Position on changes in pasture growth rate over time were analysed using repeated measures ANOVA. Data were analysed using GenStat version 12.

\section{Results and Discussion}

\section{Soil organic matter}

Position affected total soil $\mathrm{C}$ concentrations $(\mathrm{P}=0.030)$ and stocks $(\mathrm{P}=0.045)$ and $\mathrm{N}$ concentrations $(\mathrm{P}=0.030)$ and stocks $(\mathrm{P}=0.026)$; there was more soil $\mathrm{C}$ and $\mathrm{N}$ in the humps and slopes than the hollows, while the $\mathrm{C}: \mathrm{N}$ ratio was less affected by Position $(\mathrm{P}=0.06)$ (Tables 2 and 3). Although mean total soil $\mathrm{C}$ and $\mathrm{N}$ tended to be higher after 10 years (Table 2) these differences were not significant $(\mathrm{C}$ concentrations and stocks were $\mathrm{P}=0.61$ and $\mathrm{P}=0.70$, respectively; $\mathrm{N}$ concentrations and stocks were $\mathrm{P}=0.25$ and $\mathrm{P}=0.39 \mathrm{~N}$, respectively). Similarly, the mean $\mathrm{C}: \mathrm{N}$ ratios were not statistically different between sites of different age $(\mathrm{P}=0.17)$. However, there was a significant interactive effect of Age and Position $(\mathrm{P}=$ 0.016) on the $\mathrm{C}: \mathrm{N}$ ratio, indicating overall the rate of change of $\mathrm{C}: \mathrm{N}$ ratio varied between the hump, slopes and hollows over time. The mean $\mathrm{C}: \mathrm{N}$ ratios were lowest after 10 years (16 to 17$)$ and were the same at all positions. Typical $\mathrm{C}: \mathrm{N}$ ratios for dairy pastures in New Zealand are about 11, whereas the high C:N ratios we observed are more typical of indigenous forest (Sparling \& Schipper 2006). High C:N ratios and increasing $\mathrm{C}$ and $\mathrm{N}$ accumulation in these soils over time would indicate that there is a high potential for fertiliser and excretal $\mathrm{N}$ immobilisation following modification, while a narrowing $\mathrm{C}: \mathrm{N}$ ratio trend suggests the quality of organic matter is improving and more nutrients are being recycled (McLaren \& Cameron 1993). Thomas et al. (2007) observed that SOM levels on hump and hollow soils increased with age. Their findings were based on a larger number of paddocks (15) from a single dairy farm complex under similar management regimes and soil type. Our total soil C and $\mathrm{N}$ measurements varied widely between sites at similar ages. This variability may be due to differences in: management practices between farms and over time; soil type, including differences in levels of soil $\mathrm{C}$ and $\mathrm{N}$ when humps and hollows were constructed; and humping and hollowing construction practices between farms and over time.

\section{Dry matter production}

DMP was strongly affected by Position $(\mathrm{P}=0.002)$. DMP increased in the order hollows $<$ slopes $<$ humps. About 50\% more DMP was produced from the humps

Figure 1 The effect of position, age and $\mathrm{N}$ fertiliser rate on DMP. Bar represents the average $\mathrm{LSD}_{5 \%}$.

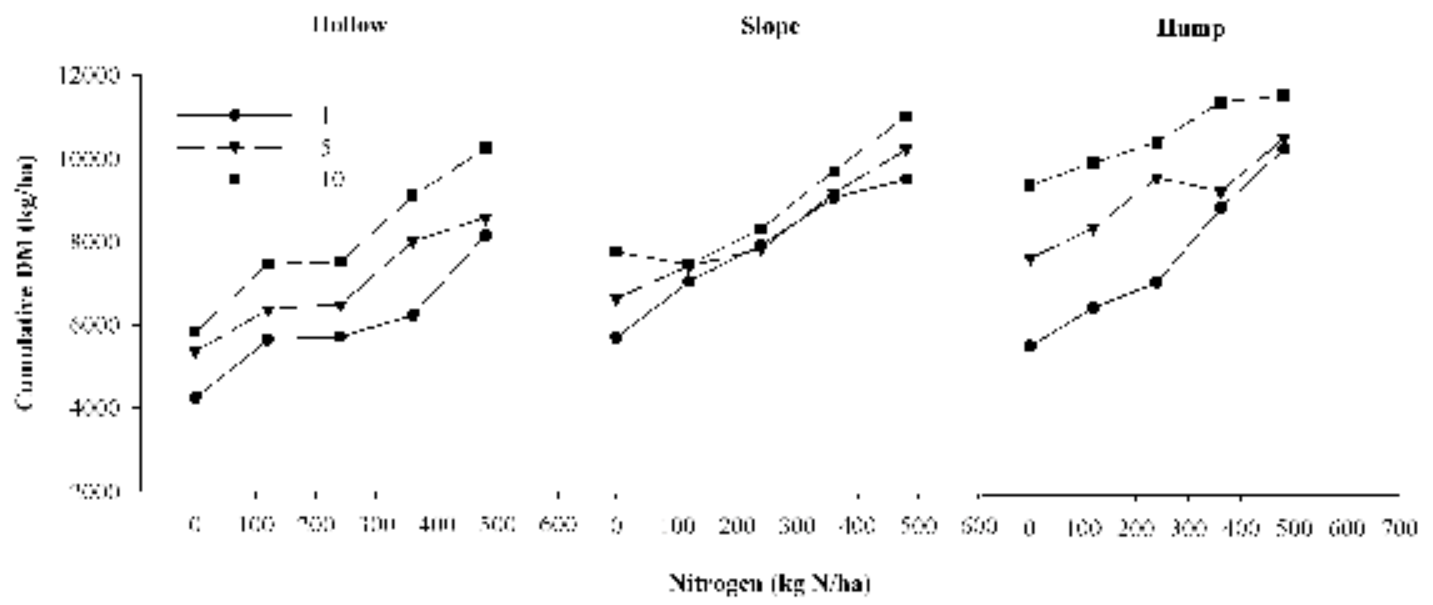


Figure 2 Species composition (\% of total pasture dry matter) in humps (black bars), slopes (white bars) and hollows (grey bars) for A) 1-year-old, B) 5-year-old and C) 10-year-old humps and hollows measured in August 2008 before $\mathrm{N}$ fertiliser application. Bar represents average $\mathrm{LSD}_{5 \%}$ for comparison of effects of age and position for each pasture species.

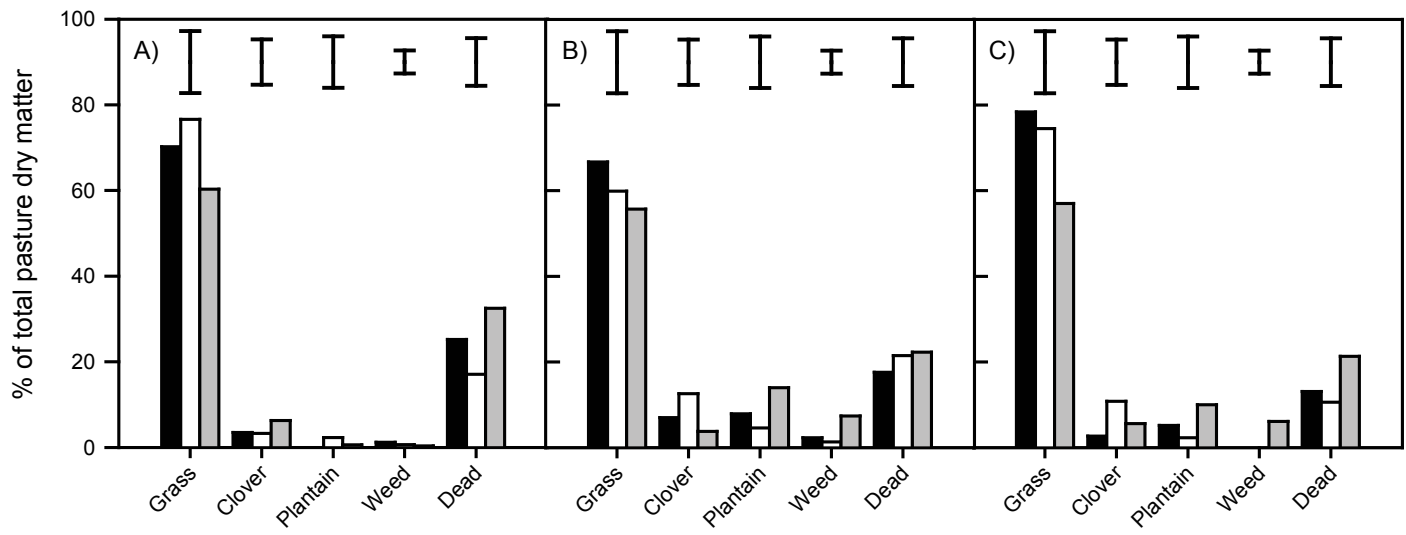

than the hollows in the control plots (no $\mathrm{N}$ fertiliser applied, Fig. 1). This strong effect did not behave independently of the Age and $\mathrm{N}$ treatment. DMP increased with increasing $\mathrm{N}$ fertiliser rates across all positions $(\mathrm{P}<0.001)$ and was influenced by age with greatest DMP occurring on the oldest soils $(\mathrm{P}=0.026)$. Though it appears that the response to $\mathrm{N}$ may not have been as strong on the humps at 10 year sites as on other sites, the DMP/kg N applied (less the control), increase in $\mathrm{kg}$ of DM (above DMP without fertiliser $\mathrm{N}$ added) $/ \mathrm{kg}$ $\mathrm{N}$ fertiliser applied, was approximately linear (Fig. 1).

The highest annual DMP (11.6 t/ha) was measured on the soils with the highest SOM with $480 \mathrm{~kg} \mathrm{~N} / \mathrm{ha}$ applied. Nearly $70 \%$ more DM was produced from the humps on control plots (no $\mathrm{N}$ applied) at the 10-year sites than from humps on the 1-year sites (Fig. 1). There was a trend for more DMP from the control plots $(0 \mathrm{~N}$ treatments) on the slope and hollow positions of the 10year than from the 1-year sites, although the differences were small ( $36 \%$ and $37 \%$, respectively). On the humps, DMP in the control plots accounted for 54, 73 and $81 \%$ of the total DMP from the highest fertiliser $\mathrm{N}$ treatment (480 $\mathrm{kg} \mathrm{N} / \mathrm{ha}$ ) and 78,80 and $90 \%$ for the $240 \mathrm{~kg} \mathrm{~N} / \mathrm{ha}$ treatment at the 1, 5 and 10 year-old-sites, respectively.

The lower DMP in the hollows at the Nil N application rate is most likely a function of the low SOM levels at this position. In the process of creating the humps and hollows the original topsoil was removed and deposited to construct the humps, leaving gravel with low amounts of fine earth mineral soil and low organic matter levels. Given the lower productivity in the hollows, there will be lower nutrient cycling and inputs from plant material and excreta over time than in the slopes and humps. In addition to limited nutrient cycling and supply due to the low levels of SOM in the hollows, the water holding capacity will also be lower and DMP may be limited due to plant water stress. In contrast, the higher DMP measured on the humps and slopes of the older paddocks is associated with the tendency of livestock to concentrate on these areas and return more dung and urine to humps and slopes. Differences in the amounts of DMP may also have been a function of different pasture composition. The amount of grass $(\mathrm{P}=0.006)$, weeds $(\mathrm{P}=0.025)$ and dead material $(\mathrm{P}=0.026)$ measured at the start of the trial varied due to Position (Fig. 2). Overall, there was less grass and more weeds and dead material in the hollows compared to the more productive slopes and humps.

\section{Pasture growth rates}

Morton \& Williams (2002) reported pasture growth rates of $3-15 \mathrm{~kg} \mathrm{DM} / \mathrm{ha} /$ day in winter, $15-50 \mathrm{~kg} \mathrm{DM} /$ ha/day in spring, 33-73 $\mathrm{kg} \mathrm{DM} / \mathrm{ha} /$ day in summer and 4-20 kg DM/ha/day in autumn, in a review of West Coast pastoral research. The growth rates measured in this study were within these ranges (Fig. 3a). There were marked effects of position on pasture growth rates throughout the year. The rate of decline in growth rates from the maximum in November was greatest in the hollows and least on the humps (Fig. 3a). The largest differences in growth rates between positions occurred between January and March 2009. In February, the pasture growth rates on the humps were almost twice the growth rates in the hollows, and about $15 \%$ more than on the slopes (Fig. 3a). Humps and slopes were likely to have supported greater amounts of more productive grass species, than the hollows that had less grass and more weedy species (Fig. 2). Drought stress may also have contributed to the lower growth rates in the hollows over this period, especially in February. The difference in daily growth rates between sites of different ages was also most evident over summer (Fig. 3b). The greater accumulation of SOM in the humps and slopes may provide some buffering against 
Figure 3 Effects of a) position and b) age of pasture on pasture growth rates. Error bar represents average $\mathrm{LSD}_{5 \%}$.

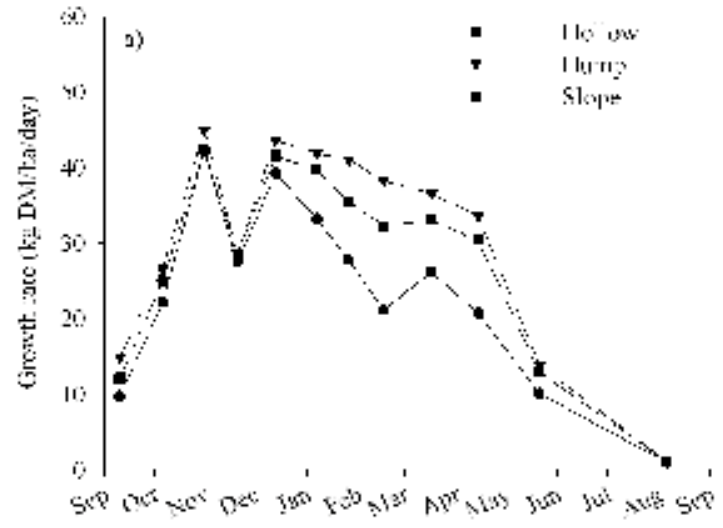

moisture-driven declines in DMP at these positions.

\section{Fertiliser $\mathbf{N}$ responses}

To achieve the same DMP in newly modified soils as in 10-year-old plots, much greater amounts of fertiliser $\mathrm{N}$ are required. About $480 \mathrm{~kg} / \mathrm{ha} / \mathrm{yr}$ of fertiliser $\mathrm{N}$ was needed to achieve $10 \mathrm{t} / \mathrm{ha}$ of annual DMP in 1-yearold sites, only about $240 \mathrm{~kg} / \mathrm{ha} / \mathrm{yr}$ of fertiliser $\mathrm{N}$ was needed to achieve this level at 10-year-old sites (Fig. 1). Previous studies have recognised that high capital fertiliser rates are required on newly developed West Coast soils (e.g. Smith et al. 1976) with 240 to 480 $\mathrm{kg} \mathrm{N} / \mathrm{ha} / \mathrm{yr}$ required for maximum pasture production in the first 2 years of development (Morton \& Roberts 2006).

Regression analysis of the cumulative DMP data gave a predicted DM response to added $\mathrm{N}$ of $7.3 \mathrm{~kg}$ $\mathrm{DM} / \mathrm{kg} \mathrm{N}$, regardless of Age or Position (Fig. 1). This is at the lower end of the 7 to $15 \mathrm{~kg} \mathrm{DM} / \mathrm{kg} \mathrm{N}$ range of DMP responses to applied $\mathrm{N}$ found on the West Coast by Williams \& Paterson (1983). It is also lower than DMP responses of 9 and $15 \mathrm{~kg} \mathrm{DM} / \mathrm{kg} \mathrm{N}$ measured in a cattle-grazed trial in Southland at fertiliser rates of 400 $\mathrm{kg} \mathrm{N} / \mathrm{ha}$ and $100 \mathrm{~kg} \mathrm{~N} / \mathrm{ha} \mathrm{(Monaghan} \mathrm{et} \mathrm{al.} \mathrm{2005),} \mathrm{but}$ within the range expected for intensive pasture (Kemp et al. 1999). A low fertiliser $\mathrm{N}$ efficiency indicates that at these application rates a large amount of the $\mathrm{N}$ applied is being lost through leaching, denitrification or immobilisation by soil microbial biomass. In contrast to the linear response of DMP to applied N (Fig. 1), typically as fertiliser $\mathrm{N}$ application rates increase there is a diminishing DM response to applied $\mathrm{N}$ in permanent long-term pastures (Ball \& Field 1982). Based on the high C: $\mathrm{N}$ ratios and relatively low fertiliser $\mathrm{N}$ efficiency, even at high $\mathrm{N}$ application rates, immobilisation is likely to be a major process for the accumulation of soil N. In long-term intensively managed pastures high rates of immobilisation of between 15 and $23 \%$ of the

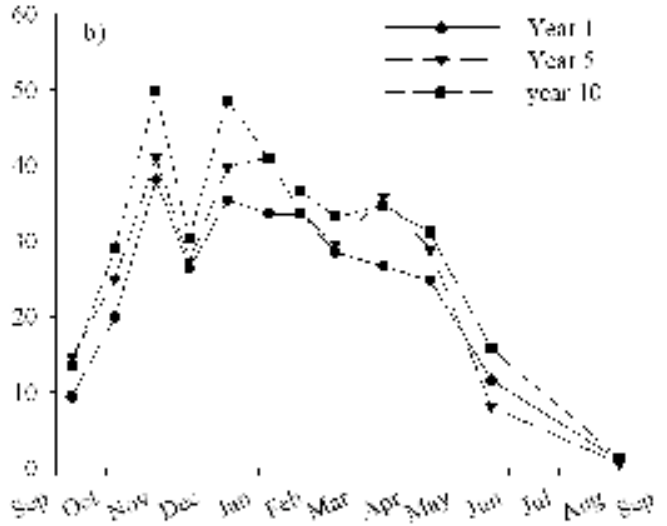

fertiliser $\mathrm{N}$ applied have been observed (Ledgard et al. 1999). Leaching losses from these soils may also be high due to high rainfall and drainage amounts with the proportionally larger losses likely to occur with increasing $\mathrm{N}$ rates (Ledgard et al. 1999). Over time as the levels of organic $\mathrm{N}$ build up and $\mathrm{C}: \mathrm{N}$ ratios decline, the amount of $\mathrm{N}$ immobilisation would be expected to decrease and the amount of net mineralisation of organic $\mathrm{N}$ is likely to increase. This will have implications for increasing DMP and fertiliser $\mathrm{N}$ requirements.

These results indicate that SOM is an important source of plant-available $\mathrm{N}$ as hump and hollow soils develop after modification. Some of the $\mathrm{N}$ supplied in the $0 \mathrm{~N}$ treatments was undoubtedly due to the increased presence of $\mathrm{N}$-fixing clover. The potential to develop strategic fertiliser management practices that increase the contribution of clover-fixed $\mathrm{N}$ to the $\mathrm{N}$ fertility of hump and hollow systems requires further investigation. There is perhaps opportunity to apply strategic applications of $\mathrm{N}$ up to $240 \mathrm{~kg} \mathrm{~N} / \mathrm{ha} /$ annum and retain a high clover content and $\mathrm{N}$ fixation input. Morton \& Roberts (2006) observed that after 2 years following modification an application rate of $240 \mathrm{~kg} \mathrm{~N} /$ ha/year produced 85 and $92 \%$ of the DMP at $480 \mathrm{~kg} \mathrm{~N} /$ $\mathrm{ha} / \mathrm{yr}$ at two different humps and hollow sites.

\section{Conclusion}

As the modified soils develop over time, annual rates of DMP increase. More DM can be produced with less $\mathrm{N}$ inputs on the older soils compared with the newly modified soils. Levels of SOM tend to increase with time and typically high initial $\mathrm{C}: \mathrm{N}$ ratios may be expected to decrease. Levels of SOM are not the same across the hump and hollow formations. Most DM was grown on the humps and slopes where SOM was highest. Building up the levels and quality of SOM in these recently modified soils is important for nutrient cycling and water storage. Much of the $\mathrm{N}$ applied or 
returned as excreta is likely to be immobilised. As the amount of SOM increases from returns of plant organic matter and animal excreta the quality of SOM improves, providing mineralised nutrients from SOM for DMP.

These findings have implications for fertiliser management as the soils develop. An understanding of these relationships will help to predict DMP on the humps, slopes and hollows in a paddock. This will be useful in allocating cows to paddocks in terms of adequate feed intakes. This information will also be useful to farmers in directing $\mathrm{N}$ fertiliser at different rates across the paddock to attain DMP targets.

\section{ACKNOWLEDGEMENTS}

We are grateful for the support of: Colin Van der Geest, Shane Kelly and Noel Rob for providing the trial sites and assisting with setting up the trials on their farms; the Ministry of Agriculture and Forestry's Sustainable Farming Fund, Landcorp Farming Ltd, DairyNZ, Westland Milk Products and Ballance AgriNutrients for support of the project; Richard Gillespie, Peg Gosden, Rebekah Tregurtha, Richard Sim, Mike George and Lesley Corbett for assistance with field work. Thanks also to the two reviewers who provided valuable comments that improved the manuscript.

\section{REFERENCES}

Ball, P.R.; Field, T.R.O. 1982. Responses to nitrogen as affected by pasture characteristics, season and grazing management. pp. 45-64. In: Nitrogen fertilisers in New Zealand agriculture. Ed. Lynch, P. B. Ray Richards \& New Zealand Institute of Agricultural Science, Auckland.

Kemp, P.D.; Condron, L.M.; Matthew, C. 1999. pastures and soil fertility. pp. 67-82. In: New Zealand pasture and crop science. Eds. White, J.; Hodgson, J. Oxford University Press, Auckland.

Ledgard, S.F.; Penno, J.W.; Sprosen, M.S. 1999. Nitrogen inputs and losses from clover/grass pastures grazed by dairy cows, as affected by nitrogen fertilizer application. Journal of Agricultural Science, Cambridge 132: 215-225.

McDowell, R.W. 2008. Phosphorus in humped and hollowed soils of the Inchbonnie catchment, West Coast, New Zealand: II. Accounting for losses by different pathways. New Zealand Journal of Agricultural Research 51: 307-316.
McLaren, R.G.; Cameron, K.C. 1993. Soil Science. An introduction to the properties and management of New Zealand Soils. Oxford University Press, Auckland.

Molloy, L. 1998. Soils in the New Zealand landscapethe living mantle, 2nd edition. New Zealand Society of Soil Science, Canterbury.

Monaghan, R.M.; Paton, R.J.; Smith, L.C.; Drewry, J.J.; Littlejohn, R.P. 2005. The impacts of nitrogen fertilisation and increased stocking rate on pasture yield, soil physical condition and nutrient losses in drainage from a cattle-grazed pasture. New Zealand Journal of Agricultural Research 48: 227-240.

Morton, J.D.; Roberts, A.H.C. 2006. Pasture responses to fertiliser on renovated West Coast pakihi soils. Proceedings of the New Zealand Grassland Association 68: 331-338.

Morton, J.D.; Williams, P.H. 2002. A review of pastoral research carried out on the West Coast of the South Island: 1960-2000. Proceedings of the New Zealand Grassland Association 64: 11-16.

Smith, G.S.; Middleton, K.R.; Smith, R.G. 1976. Diagnosis of multiple plant-nutrient deficiencies in soils of the west coast of the South Island. I. "Pakihi" soils New Zealand Journal of Experimental Agriculture 4: 423-428.

Sparling, G.; Schipper, L. 2004. Soil quality monitoring in New Zealand: trends and issues arising from a broad-scale survey. Agriculture Ecosystems \& Environment 104: 545-552.

Thomas, S.M.; Beare, M.H.; Ford, C.D.; Rietveld, V. 2007. Changes in soil quality following humping/ hollowing and flipping of pakihi soils on the West Coast, South Island New Zealand. Proceedings of the New Zealand Grassland Association 69: 265-270.

Williams, P.H.; Paterson, D.J. 1983. Response of pastures to nitrogen fertiliser applied in autumn and spring on the West Coast of South Island, New Zealand. New Zealand Journal of Experimental Agriculture 11: 247250. 